ISSN: 2224-0616

Int. J . Agril. Res. Innov. \& Tech. 6 (2): 69-76, December, 2016 Available online at http://www.ijarit.webs.com

\title{
EFFECT OF SOURCE-SINK MANIPULATION ON YIELD AND RELATED YIELD COMPONENTS IN CASSAVA, Manihot esculenta Crantz
}

\author{
Amarullah', D. Indradewa' ${ }^{2}$ P. Yudono ${ }^{3}$ and B.H. dan Sunarminto ${ }^{4}$
}

Received 19 October 2016, Revised 13 December 2016, Accepted 27 December 2016, Published online 31 December 2016

\begin{abstract}
The distribution of nutrients and assimilates in different organs and tissues is in a constant state of flux throughout the growth and development of a plant. At key stages during the life cycle, profound changes occur, and perhaps one of the most critical of these is during tubers filling. The purpose of this study was to examine the effect of sources- sink manipulation to related yield and yield components of cassava cultivars Singgah. Experiment manipulation source using number of branches cropping (S) which consists of three levels i.e. S1: 1 branch planting; S2: 2 branches planting; S3: 3 branches planting and manipulation at the bottom of that manipulation of the bottom with the model sliced the bottom of the cuttings (L) which consists of three levels i.e. L1: Sliced flat cuttings; L2: Sliced oblique cuttings; L3: Sliced cuttings of two sloping sides. In the cassava plant there is a relationship between the source and the bottom. Manipulation treatment plant cassava with two branches crop resources, if interaction the bottom with the model manipulation cuttings incision flat base capable of increasing biomass as well as the amount of cassava tuber crop plant varieties Singgah. The diameter of the tubers if interaction with wedge base model of cuttings oblique slices one general interaction and manipulation of two branches crop with all models of the base of the cuttings slice significantly improves weight of tuber crop.
\end{abstract}

Keywords: Sink-source, Manipulation, Yield, Cassava

${ }^{1}$ Department of Agronomy, Faculty of Agriculture, University of Borneo Tarakan, Jl. Amal Lama 1, Tarakan. North Borneo, Indonesia

${ }^{2 \&, 3}$ Department of Agronomy, Faculty of Agriculture, Gajah Mada University, Jl. Flora, Bulaksumur. Yogyakarta, Indonesia

${ }^{4}$ Department of Soil Science, Faculty of Agriculture, Gajah Mada University, Jl. Flora, Bulaksumur. Yogyakarta, Indonesia

*Corresponding author's email: amarullah70@gmail.com (Amarullah)

\section{Introduction}

Prospects for the development of cassava commodities continued to increase in line with the increasing diversification of needs for raw materials are sourced from cassava. In some countries, cassava is the staple food and some are used for processed into food alternatives. The economic value of cassava can be enhanced when used as biofuels, especially with the depletion of world oil reserves that make cassava demand is increasing in some other countries (Amarullah et al., 2016). A substantial increase in yield potential are needed to ensure food security in the coming decades. In striving to improve yield potential, it is important to determine the physiological factors limit results. The first step towards this is to evaluate whether the harvested organ growth is limited by the availability of a substrate or with the organ's capacity to absorb and utilize substances that are available for growth. In plant system, source-sink relationship is a complex phenomenon (Basuchaudhuri, 2016). Attempts to identify the physiological factors limit the results should integrate sources and sink interaction both spatially and temporally. Relations sink-sources can be defined as the ability of plants to undergo photosynthesis, thus improving the $\mathrm{CO}_{2}$ at the source of organs, and to transport the carbon is fixed into various tissue depths. It also defines the bottom of the organ's ability to assimilate carbon structures remain. Wine ability to perform these functions based on genotype, the environment in which it is located (abiotic factors), and viticultural management practices do it (J oubert, 2012). Plant functions depend on the carbon source, and transport and assimilation thereof is very important. The movement of water and solutes occurs through the xylem and phloem tissue. Certain solutes such as calcium network exclusive phloem, xylem, or sugar, which is done through the phloem. Source network includes the organs that are capable of exporting solutes. These organs are where the compound is produced or stored and where the compound is delivered. Organ tissue depths show that the solute is sent and used for metabolic processes and growth 
(Iland et al., 2011). Plant grouth is closely correlated to the power source and the bottom, and the balance between them. Source of plant vigor is defined as the rate at which plants produce assimilation (photosynthesis rate). The strength of the bottom of the plant consists of the strength of the bottom of all individual organs. The strength of the bottom of an organ is the competitive ability of the organ to attract assimilation and can be measured by its. Potential growth rate, Although the fruit is great depths organ in plants such as tomatoes, also the leaves, stem and root exploit deep assimilation and strength; then the leaves are not only a source of organs, but also organs depths. Activity organ source and the depths of seemingly coordinated closely to achieve a balance between supply and demand of carbohydrates in the number of plants. Keseimbangan sourcereservoir of carbon in plants regulates status (Osorio et al., 2014). Balance difference sourcereservoir is expected to make a difference in carbohydrate content in plants (Patrick and Colyvas, 2014). In Resource-limited situation, the carbohydrate content in the plant may be low as the plants should be deep enough to take advantage of assimilation produced. However, in plant grouth of limited depths situation can not compensate for assimilate production. When assimilate production exceeds the utilization of carbohydrates (starch and soluble sugars) are usually stored in the leaf as well as rod (Scofield et al., 2009). Limited demand depths can produce feedback regulation of photosynthesis because it can down-regulate net photosynthesis. Activities through the accumulation of carbohydrates in the leaves of the source (VelezRamirez et al., 2014). Manipulating the organ source and the bottom (e.g. pruning of fruit and leaves) are often applied to investigate the balance of source-reservoir plants (Matsuda et al., 2011). Crop growth models can be used to measure the power source and the bottom (Wubs et al., 2009). In this model, the strength of the bottom of the organ that develops is determined by the level of potential growth (i.e. growth under non-limiting supply assimilate), which depending on stage of development. Accumulated power of the bottom of each organ on the crop yields on total strength of the bottom of the plant. Strength plant sources is calculated as the supply of assimilation during the day, which is estimated by the rate of plant growth ( $\mathrm{g}$ dry mass of plant ${ }^{-1}$ day $^{-1}$ ) performance of photosynthesis and development of reproductive organs directly or indirectly affect the source-sink relationships and thus assimilate partitioning between plant organs (Max et al., 2016). Grouth environment plays an important role in determining the balance of the source-reservoir. In the non-stressed conditions, the radiation is very important because it is the direction of force for photosynthesis. Additional lighting is generally applied in the greenhouse in order to improve plant photosynthesis and thus production (Moe et al., 2006). The beneficial effects of supplemental lighting is determined by the balance between assimilate production in source leaves and the overall capacity of the plant to use assimilate. This means that it is important to identify the source-reservoir balance of the plant to efficiently utilize the extra lighting. The balance of the source-reservoir plants vary significantly during its life span due to the initiation and development of organs that affect both the strength of the source and reservoir (Iland et al., 2011). During the early stages of growth, tomato plants may be vulnerable to the limitations of the bottom as there may be deep enough to take advantage of all the resulting assimilation. This may occur especially under high radiation. During the reproductive phase, tomato plants generally produce much fruit, and assimilate the supply may not meet demand depths. It's been suggested in studies where pruning fruit size increase fruit left 8 without affecting the total production of biomass plants (Matsuda et al., 2011). The balance of the sourcereservoir could also differ between cultivars are often different in loads of fruit and fruit growth rate potential, showed the depths of the power difference. Cultivars may also vary in strength as the source of the property leaf photosynthesis, leaf area and plant architecture may be different. Dueck et al. (2010) observed that under the influence of additional lighting management of commercial crops that are small in comparison with the cherry tomato cultivars with large-sized fruits. A large bottom size, as well as efficient transport of photo-assimilates from the leaves and stems to develop the sink are required in the manufacture of high yield and high harvest index of the entire plant. In addition, the capacity to transport the photo-assimilates from the source to the bottom (e.g. the number of large vascular bundle) could also be a photo-assimilate the basic limitations of grain filling. A manufacturer that has been optimized source-sink ratio it can grow using a balanced allocation of the size of the resources and activities of the depths. Evidence that growth largely controlled by both the strength of the source and the bottom comes from the manipulation experiments and studies of natural variation between species. Manipulating the balance of the show source-reservoir that is the source and sink strength often operating below their full potential, because of the limitations imposed by environmental changes and development are discussed above. Increasing carbon sink capacity under increased $\mathrm{CO} 2$, using superior cultivars or adding nitrogen, facilitate increased photosynthesis (Aranjuelo et al., 2013). Positive yield response to effects at the level of 
assimilate source (leaf area and photosynthesis) and at the level of assimilate sinks (number of roots, mass, fruits, etc.) (Edet et al., 2015). In Cassava, yield is closely associated with tuber diameter, size and weight (Ntawuruhunga and Dixon, 2010; Agahie et al., 2011). The shoot and the root compete for photosynthetic assimilates due to cassava's unique simultaneous development of these two sinks, however, to achieve high yield, shoot and root growth must be well balanced (Edet et al., 2015). The purpose of this study was to examine the effect of sources and sink manipulation to yield and related yield components of cassava cultivars Singgah.

\section{Materials and Methods}

\section{Experiment site}

The field study was conducted on the ground in the garden Inceptisol University of Gadjah Mada, Yogyakarta Indonesia during January and November 2014. Research station is situated at altitude $113 \mathrm{~m}$ above mean sea level.

\section{Experiment design}

Research using stem cuttings of cassava varieties of Singgah in a randomized block design (RBD) with three replications. Experiments using two factors: the first factor is the manipulation at the source, i.e. regulating the number of branches cropping (S) which consists of three levels i.e. S1: 1 branch planting; S2: 2 branches planting; S3: 3 branches planting and the second factor is the manipulation at the bottom of that manipulation of the bottom with the model sliced the bottom of the cuttings (L) which consists of three levels i.e. L1: Sliced flat cuttings; L2: Sliced oblique cuttings; L3: Sliced cuttings of two sloping sides.

\section{Implementation of field research}

Planting activity conducted in stages; tillage and planting material, planting, maintenance and harvesting. Size $\pm 20 \mathrm{~cm}$ cuttings material and planted upright in research plots measuring $5 \times 7$ $\mathrm{m}$ with spacing of $1 \mathrm{~m} \mathrm{x} 1 \mathrm{~m}$ (population of 525 plants or the equivalent of 10,000 plants ha-1). Cassava plant maintenance is done in a way; weeding two times before fertilization and in conjunction with hoarding to soil by loosening the soil, fertilizing with urea, SP36 and $\mathrm{KCl}$ at a dose of 200,100, and $100 \mathrm{~kg} \mathrm{ha}^{-1}$, given half doses at age 1 month, then the rest is given again at age 3 month. While organic fertilizers such as manure is given at the age of 1 month with a rate 20 ton ha- ${ }^{-1}$.

\section{Yield and Observation}

Observation of agronomic character including; plant height, leaf number, stem diameter, number of tubers, tubers length, diameter and fresh weight of cassava tubers. While the yield components and tuber yield, include; fresh weight of tuber per hectare, harvest index (HI), tubers dry matter, starch content and cyanide content.

Harvest index (HI) calculated from the following formula:

$$
\text { HI }=\frac{\text { Yield economy }}{\text { Yield ecology }} \text { x } 100
$$

\section{Statistical analysis}

The data were analyzed by analysis of variance, when there significant followed by Duncan's Multiple Range Test (DMRT) at level 5\% error. Relationships between variables observations sought by correlation. Data were processed using SAS program Portable 9.1.3 for the F test and SPSS 19 for correlation.

\section{Results and Discussion}

Statistical analysis showed significant differences some agronomic and growth characteristics affect manipulation source-sink the cassava varieties of Singgah, as shown in Table 1.

Table 1. Agronomic and growth characteristics affect manipulation source-sink in cassava varieties of Singgah.

\begin{tabular}{|c|c|c|c|c|c|c|}
\hline \multicolumn{2}{|l|}{ Treatment } & \multicolumn{5}{|c|}{ Agronomic and growth characteristics } \\
\hline $\begin{array}{l}\text { Number of } \\
\text { branch per } \\
\text { planting }\end{array}$ & $\begin{array}{lcc}\begin{array}{l}\text { Model sliced } \\
\text { bottom of }\end{array} & \text { the } \\
\text { cuttings } & & \text { the }\end{array}$ & $\begin{array}{l}\text { Plant height } \\
\text { (cm) }\end{array}$ & $\begin{array}{l}\text { Number } \\
\text { of leaf }\end{array}$ & $\begin{array}{l}\text { Diameter of } \\
\text { stem }(\mathrm{cm})\end{array}$ & $\begin{array}{l}\text { Leaf area } \\
\text { index }\end{array}$ & $\begin{array}{ll}\text { Leaf } & \text { area } \\
\text { duration } & \end{array}$ \\
\hline \multirow[t]{3}{*}{1} & Flat & 197.43abc & $85.67 a$ & $2.84 a$ & $3.51 \mathrm{bc}$ & 3586.99cd \\
\hline & Oblique & 202.92ab & 69.73abc & $2.85 \mathrm{a}$ & $3.34 \mathrm{c}$ & 3210.81cd \\
\hline & Two sloping sides & 207.22ab & $87.07 \mathrm{a}$ & 2.81a & $3.39 \mathrm{c}$ & 3287.76d \\
\hline \multirow[t]{3}{*}{2} & Flat & 194.04abc & 65.13abc & 2.31b & $4.59 \mathrm{a}$ & 4848.98a \\
\hline & Oblique & 189.73abc & 66.19abc & $2.21 \mathrm{bc}$ & $4.08 \mathrm{abc}$ & 4051.93abcd \\
\hline & Two sloping sides & $210.46 a$ & 75.83ab & $2.35 \mathrm{~b}$ & $4.40 \mathrm{ab}$ & 4325.38abc \\
\hline \multirow[t]{3}{*}{3} & Flat & 193.83abc & $56.91 \mathrm{bc}$ & $2.03 \mathrm{bc}$ & $4.49 \mathrm{a}$ & 4438.40ab \\
\hline & Oblique & $185.78 b c$ & $48.02 \mathrm{c}$ & $1.87 \mathrm{~d}$ & $3.26 a b c$ & 3537.74bcd \\
\hline & Two sloping sides & $179.45 \mathrm{c}$ & $49.84 \mathrm{c}$ & $1.98 \mathrm{~d}$ & $3.88 \mathrm{abc}$ & 3766.33abcd \\
\hline
\end{tabular}

The average values followed by the same letters in the same column are not significantly different at 5\% DMRT. 
Leaf growth because of manipulation of the sink and source. Growth and development of the leaves indicates the leaf area index (LAI). The ability of plants to perform photosynthesis is determined by the broad leaves because of the greater leaf area, the greater the light that can be locked up by plants Repairs way of cultivation of cassava by manipulation of the number of branches cropping and models slices cuttings produce leaf area greater than without manipulation and able to improve LAI in the vegetative phase to a maximum of $65.73 \%$ and $85.97 \%$ in the phase of tuber formation. There is no interaction between the base of the wedge models cuttings with a number of branches of the LAI in the phase of maximum vegetative and charging tubers. There is a tendency to increase the number of branches lead to LAI is getting old, but an increase in planting two branches longer than the three branches of cultivation. At maximum vegetative phase, the plant at the base of the cuttings flat, sloping one or two sides, increasing the number of branches over an increasingly long lead LAI significantly, except for plants with root cuttings tilted one side with the number of branches of the three crops. In the charging phase of tubers, cuttings of plants with a flat base, increase the number of branches is more than one real prolong the life of leaves but not in any of the plants with the base of the cuttings tilted to one side. At the base of the cuttings of plants with two sloping sides, increasing the number of branches of two cropping improve LAI significantly, though not in any of the three branches of cultivation. Two branch source manipulation and manipulation planting depths with the base model of the slices flat cuttings able to extend the leaf area duration (LAD). Cassava plants with a treatment interaction manipulation two branches planting cuttings base model with a flat wedge has a longer duration of leaf area and significantly different from the interaction of one branch with all models of the base of the cuttings slices. Plants with two branches treatment of manipulation source cropping, interaction with the model base of the cuttings oblique slices one or two real side has a higher biomass results from the interaction of other manipulations. Tuber growth by the manipulation of sink and source in the cassava plant, a major storage organ in the form of starch grains on some root fibers are enlarged and occurred more rapidly in the early growth phase, while others remain the root fibers whose function is to absorb nutrients through the soil. LAI calculation results in Table 1, has reached number 3 this shows that the cassava varieties Singgah including high yielding varieties, for varieties with LAI is relatively high at 0.7 to 2.7 , including high yielding cassava and LAI optimal for storage of root growth is 3.0-3.5. It is also clear that the varieties Singgah still capable of being upgraded through all the alleged manipulation of both the sink and source. This was confirmed that the LAI optimal for storage of root growth is 3.0-3.5. LAI optimum value indicates that the speed of photosynthesis has reached the maximum. LAI followed a typical sigmoid pattern with respect to time and increased with age cassava plant in most of the genotypes followed by a decline in green leaves because of abscission of old leaves and at physiological maturity suddenly all leaves dry and heavy leaf shading occurs (Basuchaudhuri, 2016). A plant with optimum LAI may have higher biological yield as well as yield (Mondal et al., 2007; Basuchaudhuri, 2016). LAI is proportional to the increase in LAD on cassava plants with the interaction with two branches crop with all models of different slices of the base of the cuttings and the interaction either one or three branches of crops with all models of the base of the cuttings slices. This indicates that the treatment of the two branches can produce leaves with optimal growth and development disebakna occurrence of positive competition between the two branches of the formation, growth and development of the leaves.

Manipulation of the source in the form of branch arrangements and manipulation planting depths in the form of a model wedge rootstock cuttings affect the growth of tubers of cassava varieties Singgah. At the base of the cuttings of plants with slices flat and sloping one or two sides, in plants by model sliced the bottom of the cuttings two sloping sides, the increase in the number of tubers occurs when branch number two at all stages of growth, although not significantly cause differences. Manipulation of the source in the form of branch arrangements and manipulation planting depths in the form of a model wedge rootstock cuttings affect the growth of tubers of cassava varieties Singgah presented in Table 2. 
Table 2. Yield and Yield Components of impact manipulation sink and source the cassava varieties of Singgah.

\begin{tabular}{llllllll}
\hline Treatment & \multicolumn{7}{c}{ Yield components and tuber yield } \\
\hline $\begin{array}{l}\text { Number of } \\
\text { branch per } \\
\text { planting }\end{array}$ & $\begin{array}{l}\text { Model sliced the } \\
\text { bottom of } \\
\text { cuttings }\end{array}$ & $\begin{array}{l}\text { Number } \\
\text { of tuber }\end{array}$ & $\begin{array}{l}\text { Length of } \\
\text { tuber } \\
(\mathrm{cm})\end{array}$ & $\begin{array}{l}\text { Diameter } \\
\text { of stem } \\
(\mathrm{cm})\end{array}$ & $\begin{array}{l}\text { Fresh } \\
\text { weight } \\
\text { tuber }(\mathrm{g})\end{array}$ & $\begin{array}{l}\text { Weight tuber } \\
\text { per plant }(\mathrm{kg} \\
\text { ha- })^{-}\end{array}$ & $\begin{array}{l}\text { Harvest } \\
\text { index } \\
(\mathrm{HI})\end{array}$ \\
\hline 1 & Flat & $10.33 \mathrm{bc}$ & $28.88 \mathrm{~b}$ & $4.12 \mathrm{c}$ & $516.48 \mathrm{ab}$ & $4.23 \mathrm{bc}$ & $0.58 \mathrm{bc}$ \\
& Oblique & $9.67 \mathrm{bcd}$ & $26.35 \mathrm{~d}$ & $4.74 \mathrm{ab}$ & $519.61 \mathrm{ab}$ & $3.73 \mathrm{~d}$ & $0.56 \mathrm{~d}$ \\
& Two sloping sides & $10.17 \mathrm{~b}$ & $25.53 \mathrm{de}$ & $4.16 \mathrm{c}$ & $448.54 \mathrm{~b}$ & $4.12 \mathrm{bc}$ & $0.59 \mathrm{a}$ \\
& Flat & $13.33 \mathrm{a}$ & $25.13 \mathrm{e}$ & $4.08 \mathrm{c}$ & $452.16 \mathrm{~b}$ & $4.41 \mathrm{ab}$ & $0.58 \mathrm{bc}$ \\
& Oblique & $8.67 \mathrm{~d}$ & $25.85 \mathrm{de}$ & $4.90 \mathrm{a}$ & $506.31 \mathrm{ab}$ & $4.60 \mathrm{a}$ & $0.56 \mathrm{~cd}$ \\
& Two sloping sides & $10.67 \mathrm{~b}$ & $27.55 \mathrm{c}$ & $4.42 \mathrm{bc}$ & $519.26 \mathrm{ab}$ & $4.57 \mathrm{a}$ & $0.57 \mathrm{bod}$ \\
& Flat & $10.67 \mathrm{~b}$ & $33.93 \mathrm{a}$ & $4.36 \mathrm{c}$ & $469.34 \mathrm{ab}$ & $4.06 \mathrm{~cd}$ & $0.56 \mathrm{bcd}$ \\
& Oblique & $8.00 \mathrm{~d}$ & $23.87 \mathrm{f}$ & $4.43 \mathrm{bc}$ & $574.46 \mathrm{a}$ & $3.24 \mathrm{e}$ & $0.51 \mathrm{e}$ \\
& Two slopingsides & $10.33 \mathrm{bc}$ & $22.74 \mathrm{~g}$ & $4.63 \mathrm{ab}$ & $448.66 \mathrm{~b}$ & $4.04 \mathrm{~cd}$ & $0.57 \mathrm{bod}$ \\
\hline
\end{tabular}

The average values followed by the same letters in the same column are not significantly different at 5\% DMRT.

In Table 2, the interaction between the base of the wedge models cuttings with the number of branches to the diameter of the bulbs in all phases of plant growth depending on the model sliced cassava root cuttings are made. At the beginning of the vegetative phase, the plant at the base of the cuttings flat increase in the number of branches is more than one significantly increasing the diameter of the bulbs, even there is a difference between one, two or three branches of the diameter of the tubers. At the base of the plant with cuttings oblique one hand, the increase in the number of branches is more than one increase the diameter of the bulbs, the two branches of a long tuber crops increases significantly. At the base of the cuttings of plants with two sloping sides, increasing the number of branches is more than one cause the length tuber inhibited significantly, even there is a difference between one, two and three branches of the diameter of the tubers. Interaction between the bases of the wedge models cuttings with a number of branches of the heavy each tuber at all phases of the cassava plant growth. At the beginning of the vegetative phase, the plant at the base of the cuttings flat increase in the number of branches of two each tubers significantly increase the weight but increase in the three branches each tubers actually lose weight, though not real. At the base of the plant with cuttings oblique one hand, the increase in the number of branches is more than one decrease each tubers weight significantly. At the base of the cuttings of plants with two sloping sides, increasing the number of branches over an increase weight gain increase each tubers although only two branches cause a real difference. At maximum vegetative phase, the plant at the base of the cuttings flat, increasing the number of branches is more than one each tubers increase weight gain, but increase significantly when the number of branches increased from two to three. Instead, cuttings tilted one side each tuber had lower weight gain significantly; even there is a difference between one, two and three branches. At the base of the cuttings of plants with two sloping sides, increasing the number of branches over an increase weight gain each tubers significantly, even there is a difference between one, two and three branches. In the charging phase of tubers, cuttings of plants with a flat base, increase the number of branches is more than one loss each tubers, despite the decline significantly only in two branches of cultivation. At the base of the plant with cuttings oblique one hand, the increase in the number of branches each tubers lose two but three branches of crops actually increase weight each tubers, although two and three branches of cultivation does not cause a real difference. In plants with root cuttings two sloping sides, increasing the number of branches is more than one, improving each tuber but tuber weight significantly. Differences in the cassava tuber yield are determined by several factors, such as the number of tubers, tubers long and weights. Ntawruruhunga and Dixon (2010) concluded that the number and size of the diameter of the tubers is a component of the main results that contribute to a rise in cassava. A high number of tubers on the variety Singgah with sliced flat base of the branch and the branch number are not consistent with the results of tuber weight. These results supported the research of Richardson (2011), which indicates that there is a negative correlation between the number of tubers per plant and mean weight of cassava tubers. Heavy tuber crop lower the number of tubers that many presumably because competition between the roots of the tubers during the charging process. This more considerable decrease in yield shows that leaf has an important role in charging tuber phase. Supply more assimilates from other sources can somewhat compensate the lack of leaf. The leaf blade is the principal source of photo assimilates imported by charging tuber phase. However, removal of the leaf may lead in some circumstances to enhancement of the 
photosynthetic activity of other leaves and green parts of plant and remobilization of stored carbohydrates. These mechanisms avoid the restriction of charging tuber phase in such a manner that often no source limitation occurs (Shokri et al., 2009). The comparison between control and defoliated plants with decrease number of shoot indicates that differed in the ability to remobilize reserves from the stems to the tubers. Such differences in the response to availability of photo assimilates seem to be the consequence of different patterns of photo assimilate partitioning between treatment with varying source and sink ratios. One of the ways for increasing photosynthesis is sink demand. The sink demand will be increased when there are more tubers, thus the leaves will have more photosynthesis and considering that radiation rate for photosynthesis is more in climate condition, and so further tuber number may increase the sink demand and yield. Khorasani et al. (2012) reported that the yield reduction in the pod removal treatment, are more than leaf removal treatment and the yield has not been reduced, it means that the plant confronts surplus of photosynthetic materials in leaf removal condition. In Cassava, yield is closely associated with tuber diameter, size and weight (Ntawuruhunga and Dixon, 2010; Agahie et al.,
2011). The shoot and the root compete for photosynthetic assimilates due to cassava's unique simultaneous development of these two sinks, however, to achieve high yield, shoot and root growth must be well balanced. Tewodros and Ayenew (2012) observed that plant height showed strong and positive correlation with most of the characters including leaf area, fresh root and dry matter yield. Positive contribution of LAI to yield of cassava has been reported. Partitioning of assimilates in favor of cassava shoot due to age has also been reported (Edet et al., 2015). According to Apea-Bah et al. (2011), higher accumulation of starch at later stages of growth was due to conversion of glucose making $24 \mathrm{MAP}$ cassava unpalatable and uneconomical time wise. Furthermore, delay in harvest beyond 15 MAP leads to the re-assimilation of reserve food for further development thereby decreasing the regeneration capacity of cuttings. Manipulation of the source and the bottom of improving weight tuber per planting from without manipulation weighing $7.98 \mathrm{~kg}$ crop increased so weighs $8: 07$ kg crop, weight tuber per planting highest obtained at interaction manipulation of resources in the form of a number of branches as much as two branches cropping and manipulation bottom of the form the model sliced root cuttings 2 sloping sides weighs $9: 17 \mathrm{~kg}$.

Table 3. Dry matter, starch content and cyianide content of tubers impact manipulation sink and source the cassava varieties of Singgah.

\begin{tabular}{lllll}
\hline Treatment & & \multicolumn{3}{l}{ Dry matter, starch and cyanide content of tubers } \\
\hline $\begin{array}{l}\text { Number of branch } \\
\text { per planting }\end{array}$ & $\begin{array}{l}\text { Model sliced the bottom } \\
\text { of the cuttings }\end{array}$ & Dry Matter & Starch Content & Cyanide Content \\
\hline 1 & Flat & $8.60 \mathrm{a}$ & $24.59 \mathrm{bc}$ & $133.64 \mathrm{bcd}$ \\
& Oblique & $8.65 \mathrm{a}$ & $27.20 \mathrm{ab}$ & $134.19 \mathrm{ab}$ \\
& Two sloping sides & $8.64 \mathrm{a}$ & $28.39 \mathrm{a}$ & $134.64 \mathrm{a}$ \\
& Flat & $8.61 \mathrm{a}$ & $25.07 \mathrm{bc}$ & $133.12 \mathrm{de}$ \\
& Oblique & $8.62 \mathrm{a}$ & $26.25 \mathrm{~b}$ & $133.57 \mathrm{~cd}$ \\
3 & Two sloping sides & $8.50 \mathrm{a}$ & $26.15 \mathrm{~b}$ & $134.27 \mathrm{a}$ \\
& Flat & $8.61 \mathrm{a}$ & $25.54 \mathrm{bc}$ & $133.55 \mathrm{~cd}$ \\
& Oblique & $8.59 \mathrm{a}$ & $24.12 \mathrm{c}$ & $132.62 \mathrm{e}$ \\
& Two sloping sides & $8.63 \mathrm{a}$ & $26.73 \mathrm{~b}$ & $134.09 \mathrm{abc}$ \\
\hline
\end{tabular}

The average values followed by the same letters in the same column are not significantly different at 5\% DMRT.

Source and sink manipulation does not affect tuber dry weight but affects the levels of starch and cyanide in the cassava tuber varieties Shelter. Cassava plants with a treatment manipulation of the source with one branch of a tendency to produce starch crops with higher levels compared to two or three branches, especially if to interaction wedge base model with two sloping sides' cuttings. While the cassava plant cuttings base model with slices of two sloping sides produce cyanide with high levels despite to interaction with one, two or three branches planting

Cassava, M. esculenta belongs to the five important starch crops beside, rice, wheat, potato and maize. Especially, one of the leaders for cassava starch production, this market is supported by the government. Hence, the interest in cassava biology in respect of starch production increased during the last decades. One main focus in cassava research is the improvement of cassava as a starch crop by investigating storage root production, starch properties and to increase yield in order to attribute more value to this crop. Cassava has two types of roots; fibrous roots involved in nutrient uptake and thick storage roots containing high starch levels (up to $80 \%$ of dry weight). Fibrous roots are built at the lateral side of stem cuttings (Hostettler, 2014). During growth, some fibrous roots undergo a developmental transition to form starchy storage 
roots. This occurs by radial thickening and starch deposition in the phloem and xylem parenchyma cells (Teerawanichpan et al., 2008).

\section{Conclusion}

In the cassava plant, there is a relationship between the source and the bottom. Manipulation treatment plant cassava with two branches crop resources, if interaction the bottom with the model manipulation cuttings incision flat base capable of increasing LAI, LAD and biomass as well as the amount of cassava tuber crop plant varieties Singgah. The diameter of the tubers if interaction with wedge base model of cuttings oblique slices one general interaction and manipulation of two branches crop with all models of the base of the cuttings slice significantly improves weight of tuber crop.

\section{References}

Agahie, A.E., Baiyeri, K.P. and Ogbuji, R.O. 2011. Correlation analysis of tuber yield and yield related characters in two cassava (Manihot esculenta Crantz) morphological-types grown under nine weed management systems in the Guinea savanna zone of Nigeria. J . Appl. Biosci. 48: 3316- 3321.

Amarullah, Indradewa, Yudono, D.P. and Sunarminto, B.H. 2016. Photosynthetic Activity of Superior Varieties Super and Local Cassava (Manihot esculenta Crantz) in Indonesia. J . Agric. Sci. 8: 194-200.

Aranjuelo, I., Sanz-Sáez, A., Jauregui, I., Irigoyen, J.J., Araus, J.L. Sánchez-Díaz, M. and Erice, G. 2013. Harvest index, a parameter conditioning responsiveness of wheat plants to elevated $\mathrm{CO}_{2}$. J. Exptl. Bot. 64(7): 18791892.

Apea-Bah, F.B., Oduyo, I., Ellis, W.O. and SafoKantaka, O. 2011. Factor analysis and age at harvest effect on quality of flour from four cassava varieties. World J. Dairy Food Sci. 6 (1): 43-54.

Basuchaudhuri, P. 2016. Source-sink relationship in soybean. Centre for Info Bio Technology (CIBTech). Indian J. Plant Sci. 5(2): 19-25.

Dueck, T.A., Janse, J., Schapendonk, A.H.C.M., Kempkes, F.L.K., Eveleens-Clark, B.A., Scheffers, C.P., Pot, S., Trouwborst, G., Nederhoff, E.M. and Marcelis, L.F.M. 2010. Lichtbenutting van onder LED en SON-T belichting. Wageningen: Wageningen UR Glastuinbouw/ Plant Dynamics BV, Rapporten GTB 1040.

Edet, M.A., Eniola, H.T., Lagoke, S.T.O. and Tarawali, H. 2015. Relationship of cassava growth parameters with yield and yield related components and harvest time in Ibadan Southwestern. J. Nat. Sci. Res. 5 (9): 87-92.
Hostettler, C.E. 2014. Investigation starch metabolism in cassava (Manihot esculenta Crantz). DISS. ETH Nr. 21850. ETH ZURICH.

Iland, P., Dry, P., Proffitt, T. and Tyerman, S. 2011. The Grapevine from the Science to the Practice of Growing Vines for Wine. Patrick Iland Wine Promotions, Adelaide, South Australia. $310 \mathrm{p}$.

Joubert, C. 2012. A case study of source-sink relationships using shoot girdling and berry classification (Vitis vinifera L. cv. Cabernet Sauvignon). MSc Thesis, Department of Viticulture and Oenology, Faculty of Agri Sciences, Stellenbosch University, South Africa. $96 \mathrm{p}$.

Khorasani, S.E., Paknejad, F., Delkhos, B., Ardalan, V. and Mirtaheri, M. 2012. An Evaluation Source-Sink Limitation on Yield and Yield Component Two Cultivar Soybean. J. Basic. Appl. Sci. Res. 2(9): 9049-9055.

Matsuda, R., Suzuki, K., Nakano, A., Higashide, T. and Takaichi, M. 2011. Responses of leaf photosynthesis and plant growth to altered source-sink balance in a Japanese and a Dutch tomato cultivar. Scientia Hort. 127: 520-527.

Max, J.F.J., Scmidt, L., Mutwiwa, U.N. and Kahlen, K. 2016. Effects of shoot pruning and inflorescence thinning on plant growth, yield and fruit quality of greenhouse tomatoes in a tropical climate. J. Agril. Rural Dev. Trop. Subtrop. 117(1): 45- 56.

Moe, R., Grimstad, S.O. and Gislerod, H.R. 2006. The use of artificial light in year round production of greenhouse crops in Norway. Acta Hort. 711: 35-42.

Mondal, M.M.A., Howlader, M.H.K., Akter, B. and Dutta, R.K. 2007. Evaluation five advanced lentil mutants in relation to morphophysiological characters and yield. Bangladesh J . Crop Sci. 18: 367-372.

Ntawuruhunga, P. and Dixon, A.G.O. 2010. Quantitative variation and interrelationship between factors influencing cassava yield. J. Appl. Biosci. 26: 1594-1602.

Osorio, S., Ruan, Y.L. and Fernie, A.R. 2014. An update on source-to-sink carbon partitioning in tomato. Front. Plant Sci. 5: 516.

Patrick, J.W. and Colyvas, K. 2014. Crop yield components photo-assimilate supply- or utilisation limited-organ development? Funct. Plant Biol. 41: 893-913.

Richardson, K.V.A. 2011. Evaluation Three Cassava Varieties for Tuber and Quality Yield. Gladstone Road Agriculture Centre. Crop Research Report 4. 2011.

Scofield, G.N., Ruuska, S.A., Aoki, N., Lewis, D.C., Tabe, L.M. and J enkins, C.L.D. 2009. Starch storage in the stems of wheat plants: 
localization and temporal changes. Annals Bot. 103: 859-868.

Shokri, S., Siadat, S.A., Fathi, G., Maadi, B., Gilani, A. and Abdali Mashhadi, A.R. 2009. Effect of nitrogen rates on dry matter remobilization of three rice cultivars. Int. J. Agric. Res. 4: 213-217.

Teerawanichpan, P., Lertpanyasampatha, M., Netrphan, S., Varavinit, S., Boonseng, O. and Narangajavana, J. 2008. Influence of cassava storage root development and environmental conditions on starch granule an size distribution. Starch-Starke. 60: 696-705.

Tewodros, M. and Ayenew, B. 2012. Cassava (Manihot esculenta Crantz) varieties and harvesting stages influenced by yield and yield related components. J. Nat. Sci. Res. 2: 10.

Velez-Ramirez, A.I., Van Ieperen, W., Vreugdenhil, D., van Poppel, P.M., Heuvelink, E. and Millenaar, F.F. 2014. A single locus confers tolerance to continuous light and allows substantial yield increase in tomato. Nature communications. 5: article no. 4549. doi:10.1038/ncomms5549.

Wubs, A.M., Ma, Y.T., Heuvelink, E. and Marcelis, L.F.M. 2009. Genetic differences in fruit-set patterns are determined by differences in fruit sink strength and a source: sink threshold for fruit set. Annals Bot. 104: 957-964. 